\title{
Implementation of Health Education for The Prevention of Covid 19 In Magelang Regency
}

\author{
Alfiana Ainun Nisa ${ }^{1}$, Riyadho Santiko Adi ${ }^{2}$ \\ \{alfiana_ainun@mail.unnes.ac.id ${ }^{1}$, riyadhosantiko93@gmail.com² \} \\ Universitas Negeri Semarang, Indonesia ${ }^{1,2}$
}

\begin{abstract}
Magelang Regency is an orange zone area (as of August 31, 2020), so it is mandatory to make efforts to prevent the transmission of COVID-19. Based on the situation analysis, there are still insufficient efforts to prevent COVID-19. As for the efforts to prevent COVID-19 that have not been implemented, namely education about COVID-19, education on Adaptation to New Habits, and data collection of people elderly to COVID-19. The method used in data collection was through kuesioner need assessment for residents and Block Leader, and also from interviews with Block Leader. The results showed that the provision of education about COVID19 was able to change attitudes and improve behavior in preventing COVID-19. Providing education regarding New Habit Adaptation has not been able to change knowledge, but providing education on New Habit Adaptation has been able to improve attitudes and improve behavior in the prevention of COVID-19.
\end{abstract}

Keywords : COVID-19, health education.

\section{Introduction}

In March 2020, COVID-19 cases were first reported in Indonesia with 2 cases and since then COVID-19 has spread throughout Indonesia. In August 2020, the number of COVID-19 cases increased to 147,211 with 6,418 deaths. Central Java Province ranks third with the highest COVID-19 cases in Indonesia with 13,157 cases and 1,218 deaths. [1] Magelang Regency is one of the regencies in Central Java Province. Magelang Regency has also felt the COVID-19 pandemic. As of August 2020, Magelang Regency had 42 positive cases with 7 people having died [2].

Health education and promotion plays a major role in handling COVID-19. During the pandemic, the government has recommended all citizens to apply $3 \mathrm{M}$, namely using masks, washing hands, and maintaining distance. With good health education and promotion, the level of spread of COVID-19 can be reduced.

There is still a lot of knowledge, attitudes and behavior of residents regarding the COVID-19 pandemic. This is evidenced by the Need Assessment which was carried out by generating data. As many as $11.1 \%$ of residents did not understand the meaning of COVID-19 and the signs and symptoms of COVID-19, 88.9\% of residents still left the house even though there was no interest $77.8 \%$ of residents still do not wear a mask when leaving the house, $44.4 \%$ of residents do not understand about the New Habits Adaptation, and $44.4 \%$ of residents who leave their homes do not do Physical Distancing. 
Health Data Collection is an effort to monitor and carry out early prevention for residents who are elderly to being exposed to COVID-19. However, data collection on Health is still not comprehensive. This is evidenced by the Need Assessment that $44.4 \%$ of residents do not feel that there have been health workers who have conducted health data collection and $77.8 \%$ of residents admit that there has been no record of data entering and leaving the area.

\section{Methods}

This research was conducted to find out how the implementation of the COVID 19 education program, New Habit Adaptation education for elderly. The method used is a mixed method, namely qualitative data collection by interviewing regional heads, and qualitative by measuring the level of knowledge and attitudes. The population in this study were all heads of families in the Magelang regency. The sample was taken by random sampling.

\section{$3 \quad$ Result and Discussion}

\subsection{Results of the Data Collection Program for Eldery}

The Data Collection Program is a program used to monitor Public Health, especially during the COVID-19 Pandemic. This data collection program was carried out once. The data collection program for elderly residents was carried out by door to door for one week. This program is implemented in conjunction with educational programs so that it can make it easier for writers to implement the program. The data collection program for eldery people is expected to be the outcome of the data collection program for elderly people, namely that policy recommendations derived from policy briefs can produce a new policy in Magelang Regency. The objective of the Elderly Population Data Collection Program is that it is hoped that the output of the data collection program for elderly people can be used by stakeholders to make a new policy to prevent COVID-19 in Magelang Regency.

Based on the analysis of the situation in Magelang Regency, data collection on people elderly to COVID-19 has not been carried out. Even though the Governor of Central Java has issued letter number 443.5 / 0009625 regarding Control of the COVID-19 Pandemic and the Acceleration of Handling Elderly Groups in Districts / Cities. There are four points in letter number 443.5 / 0009625, one of which is about data collection of COVID-19 susceptible groups with comorbidities.

Covid-19 susceptible groups are toddlers, the elderly, and congenital diseases [11]. There are several residents in Magelang who are aged, and have covid-19 comorbidities. 


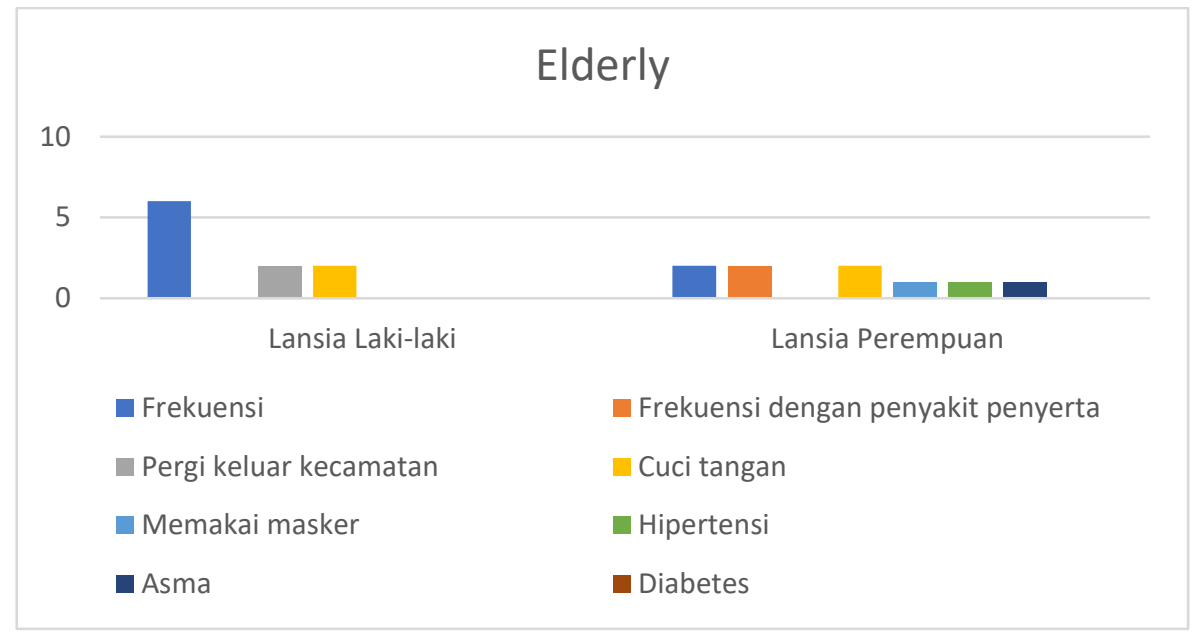

Figure 1. Distribution of Elderly by Gender, Comorbid COVID-19 and COVID-19 Prevention Behavior

The elderly are people who are elderly to contracting COVID-19. Elderly with a history of chronic disease are very at risk of being infected with the Corona Virus [11]. There are residents who have comorbidities, namely hypertension one person and asthma one person with the same person. There are two elderly who travel outside the district. The elderly who travel out of town are all male. In addition, only four elderly people who wash their hands after leaving the house, two are male and two are female. Only one elderly wears a mask when leaving the house.

\subsection{Results of the COVID 19 Education program}

The COVID-19 Education Program is a program that functions to increase public knowledge, attitudes and behavior in preventing COVID-19. COVID-19 health education program using posters, infographics, and flyers. The education provided includes information about COVID-19 such as symptoms, modes of transmission, preventive measures, issues of discrimination, HOAX news, and important information about handling COVID-19.

Table 1. Before and after health education COVID 19

\begin{tabular}{lrrrrcrccc}
\hline & \multicolumn{3}{c}{ Knowledge } & \multicolumn{4}{c}{ Attitude } & \multicolumn{3}{c}{ Behavior } \\
\hline & Good & Medium & Low & Good & Low & Good & Medium & Low \\
Before & 23,08 & 26,92 & 50,00 & 13,14 & 86,86 & 57,33 & 17,01 & 25,66 \\
After & 80,77 & 11,54 & 7,69 & 86,86 & 13,14 & 65,33 & 22,36 & 12,31 \\
\hline
\end{tabular}

At the beginning, before being given education about COVID-19, people's knowledge was low (50\%). After being given education about COVID-19, people's knowledge has increased. As many as $80.77 \%$ have good knowledge. A person's knowledge shows a behavior that is positively related to adherence [3]. Based on the 
sig statistical test, 0.006 ( $\mathrm{p}<0.05$ ), which means that Ho is rejected and $\mathrm{Ha}$ is accepted. Thus it can be concluded that there are differences / influences on the knowledge of the citizens before and after the intervention is given. It is known that 99\% of Indonesians have good knowledge, 59\% have a positive attitude, and $93 \%$ have good behavior towards COVID-19 prevention. The existence of a high level of knowledge is supported by the level of education of a community. This shows that the higher the level of knowledge, the easier it is to get information about a health problem, namely COVID-19 [4].

The attitude of the residents is quite good. Before getting education on COVID 19 , the bad attitude of residents was $86.85 \%$. After being given education about COVID-19, the attitude of the residents who were previously bad became good. This is in accordance with the literature which shows that public knowledge and prevention efforts have an interrelated relationship. Public knowledge and awareness have a high enough influence on the prevention of a disease [5]. So that there is an influence on the level of education or intelligence on public awareness in preventing COVID-19. Based on the analysis, it is obtained sig 0.006 ( $p<0.05)$, which means there is a change in attitude between before and after being given COVID-19 education.

The behavior of the residents is good, but there are still those who are still behaving badly. This is evidenced by the value of the behavior of residents when doing a pre-test before being given education on COVID 19 as many as $25.66 \%$ still have not implemented the Health protocol in their daily behavior. there are still residents who leave the house without wearing a mask, there are residents who still leave the sub-district even though they have no interest, there are residents who still do not do physical distancing, and there are residents who do not wash their hands after returning from outside the house. Based on the Wilcoxon test, it is known that the sig value is 0.006 ( $\mathrm{p}<0.05)$, which means that Ho is rejected and Ha is accepted. Thus it can be concluded that there are differences / influences on the behavior of residents before and after being given COVID 19 education. This is in accordance with the literature which states that one's experiences can increase the ability to interact with the environment. The more experience a person has, the easier it is to behave which is useful in gaining new knowledge. This is related to prevention taken to tackle COVID-19 [6].

According to B. Bloom, there are three domains of behavior, namely knowledge, attitude, and practice [7]. The implementation of health protocols in preventing COVID-19 is influenced by the knowledge and attitudes of the community. Providing education is one way to increase citizen knowledge. In the implementation of the program the author uses the offline education method by door to door. Based on the results that have been carried out after the intervention, knowledge, attitudes and behavior in implementing COVID-19 prevention for residents are getting better. This is in line with the dedication that has been carried out by Suhadi who states that after being given an offline intervention, there is knowledge and increased awareness in implementing behaviors [8]. 


\subsection{The Results Of The New Habit Adaptation Education Program}

Tabel 2. Before and after health education about adaptation to new habits

\begin{tabular}{lrrrrrrrrr}
\hline & \multicolumn{3}{c}{ Knowledge } & \multicolumn{2}{c}{ Attitude } & \multicolumn{3}{c}{ Behavior } \\
\hline & Good & Medium & Low & Good & Low & Good & Medium & Low \\
\hline Before & 8,99 & 25,11 & 65,90 & 72,00 & 28,00 & 85,40 & 11,66 & 2,94 \\
After & 70,13 & 19,66 & 10,21 & 85,40 & 14,60 & 96,10 & 2,33 & 1,57 \\
\hline
\end{tabular}

The New Habit Adaptation Education Program is a program that functions to increase people's knowledge, attitudes and behavior in implementing New Habit Adaptation. At the beginning, before being given education about Adaptation to New Habits, people's knowledge was bad. After being given education about Adaptation to New Habits, the knowledge of the residents increased. The educational program regarding the Adaptation of New Habits has been carried out once. According to the residents, education regarding the implementation of the New Habit Adaptation was very good. This can be seen from the value given to residents on the evaluation form. Education is carried out with the help of posters, infographics and leaflets. The rate of change in knowledge of knowledgeable citizens is low. Initially, 65.90\% decreased to $10.21 \%$, for respondents with good knowledge, initially it was only $8.99 \%$, increasing to $70.13 \%$. Based on the statistical test, the sig value is 0.223 ( $\mathrm{p}<0.05$ ), which means that $\mathrm{Ho}$ is accepted and $\mathrm{Ha}$ is rejected. Thus, it can be concluded that there is no difference / influence of citizen knowledge before and after the intervention is given. This is in accordance with the literature which shows that the level of knowledge is influenced by internal and external factors. One of the external factors is information, socio-culture, and environment. A person who has knowledge not only from education, but also from exposure to mass media information, namely radio, newspapers, television, magazines, and others. In addition, motivation also plays a role in a person's desire to seek information about something [7].

The attitude of the residents was classified as good. The people who had a bad attitude towards adapting to new habits before getting education were $28.00 \%$ down to $14.60 \%$ after receiving education on the adaptation of new habits. Based on statistics, it is known that the sig value is 0.076 ( $\mathrm{p}<0.05)$, which means that Ho is rejected and $\mathrm{Ha}$ is accepted. Thus it can be concluded that there are differences / influences on the attitudes of the citizens before and after the intervention is given. This is in accordance with the literature which states that the factors that influence attitudes are information and knowledge. Knowledge is the result of sensing a particular object. Attitudes based on knowledge can last longer than attitudes that are not based on knowledge [9]. This statement is in accordance with the level of knowledge, attitude and good behavior in dealing with COVID-19.

The behavior of the residents is still relatively good. This is evidenced by the value of good behavior of residents when pre-test before education was $85.40 \%$, this figure increased to 96.10 after receiving education about adaptation to new habits. Residents began to learn to live side by side with COVID 19. the house must wear a mask, there are residents who do not leave the house unless they have an interest, but there are still residents who still do not do physical distancing, and there are residents who do not 
wash their hands after returning from outside the house even though the numbers are low. The behavior of the residents increases along with the increase in people's knowledge. Based on the statistical sig test, 0.064 ( $\mathrm{p}<0.05$ ), which means that Ho is rejected and $\mathrm{Ha}$ is accepted. Thus it can be concluded that there are differences / influences on the behavior of the citizens before and after the intervention is given. This is in accordance with the literature which shows that a person's education level has an influence on knowledge. Knowledge of health, of course, also affects behavior in the medium term. So that health behavior certainly has an influence on increasing public health indicators as the output of health education [10].

\section{Conclusion}

Coronaviruses are a large family of viruses that cause illness ranging from mild to severe symptoms. Magelang Regency is feeling the impact of the COVID-19 pandemic. On August 20, 2020, Magelang Regency had 42 positive cases with 7 people dying. Prevention of COVID-19 can be done in several ways, such as providing education to residents about COVID-19, socialization and education to residents regarding the application of New Habit Adaptation.

The author provides an intervention in the form of providing education to the elderly about COVID-19, socialization and education to elderly residents regarding the application of New Habit Adaptations in Magelang Regency. Providing education about COVID-19 has been able to change attitude knowledge and improve behavior in preventing COVID-19. Providing education regarding New Habit Adaptation has not been able to change knowledge, but providing education on New Habit Adaptation has been able to improve attitudes and improve behavior in the prevention of COVID-19.

\section{References}

[1] Dinkes Kab. Magelang, D. (2020, Agustus 20). Data Pesebaran COVID-19. Retrieved From Kabupaten Magelang Tanggap COVID-19: Https://Infocorona.Magelangkab.Go.Id/

[2] SATGAS Penanganan COVID-19, S.-1. (2020, Agustus 20). Peta Sebaran Covid-19. Retrieved From Gugus Tugas Penanganan Covid-19: Https://Covid19.Go.Id/Peta-Sebaran

[3] Sari, D.P, Dan Atiqoh, N.S 2020. Hubungan Antara Pengetahuan Masyarakat Dengan Kepatuhan Penggunaan Masker Sebagai Upaya Pencegahan Penyakit Covid-19 Di Ngoronggah. Rekam Medis Dan Informasi Kesehatan. Fakultas Kesehatan, Universitas Duta Bangsa.

[4] Yanti, B., Mulyadi, E., Wahiduddin, Novika, R.G.H., Arina, Y.M.D, Martani, N.S., Nawan. 2020. Pengetahuan, Sikap, Dan Perilaku Masyarakat Terhadap Kebijakan Jarak Sosial Sebagai Sarana Pencegahan Penularan COVID-19 Di Indonesia. Jurnal Administrasi Kesehatan Indonesia, 8(1): 4-14.

[5] Bedford, J., Enria, D., Giesecke, J., Heymann, D. L., Ihekweazu, C., Kobinger, G., Wieler, L. H. 2020. COVID-19: Towards Controlling Of A Pandemic. The Lancet, 395: 1015-1018

[6] Mubarak, W. I., Nurul C., Khoirul R., \& Supriadi. 2007. Promosi Kesehatan. Ed.2. Yogyakarta: Graha Ilmu.

[7] Notoatmodjo, S. 2007. Promosi Kesehatan \& Perilaku. Jakarta: Rineka Cipta.

[8] Suhadi, Nurmaladewi, Yasnani, \& Tina, L. (2020). Promosi Kesehatan Berbasis Daring Mengenai Perilaku Pencegahan Covid-19 Bagi Masyarakat Kota Kendari. Jurnal Pengabdian Masyarakat, 245-255. 
[9] Zimmer-Gembeck, M. J. 2002. The Development Of Romantic Relationships And Adaptations In The System Of Peer Relationships. Journal Of Adolescent Health, 31(6):216-225.

[10] Putri, R. Dan Zaira N. 2017. Hubungan Tingkat Pendidikan Dan Pengetahuan Masyarakat Dengan Perilaku Pencegahan Demam Berdarah Dengue Di Desa Kemiri,Kecamatan Jayakerta, Karawang Tahun 2016. Universitas Muhammadiyah Jakarta, 1(4): 1-7.

[11] Siagian, T. H. (2020). Mencari Kelompok Berisiko Tinggi Terinfeksi Virus Corona Dengan Discourse Network Analysis. Jurnal Kebijakan Kesehatan Indonesia : Jkki, 9, 98-106. 